\title{
Oil transportation security in the Black Sea and the Turkish Straits
}

\author{
Nilufer Oral ${ }^{*}$
}

\begin{abstract}
The Black Sea region has become as an important energy transit route for Caspian and Russian oil and natural gas to western markets. Since 1996 the quantity of oil exported from the Black Sea through the Turkish Straits and the number of transiting tankers has doubled and will continue to expand. However, these are also two waterways where the risk of either an accidental or intentional disaster is significant bringing serious repercussions for energy supply security. This paper will analyze measures taken by Black Sea coastal States to provide for secure ports and shipping against accidental and intentional disasters. The paper will examine the role of technology, such as satellite based VTS providers in the Black Sea, implementation of the ISPS Code, the role of the relatively new BlackSeaFor in providing both port and navigational security. The paper will further make recommendations for further improvements for enhancement of security emergency response planning. In addition, the paper will examine current security measures taken by the Turkish Administration for oil transportation through the Turkish Straits.
\end{abstract}

Keywords: Turkish Straits, Black Sea, oil transport, ISPS Code, maritime security, BlackSeaFor.

\section{Introduction}

The Black Sea and its surrounding region, within the past decade, have emerged as an important energy transport route for global supply of oil and natural gas. During the 1990s significant new reserves of oil were discovered in the Caspian Sea, particularly rich reserves in Kazakhstan. The primary route for export of Caspian oil is by pipeline to Black Sea ports where it is loaded onto tankers for export across the Black Sea and through the Turkish Straits. Safety of

Submission Date: 25/9/2006 Acceptance Date: 30/4/2007

*Lecturer, Istanbul Bilgi University, Istanbul, Turkey, tel. +90 212311 5000/5208//E-mail:noral@bilgi.edu.tr 
navigation concerns, especially through the Turkish Straits, is important for both the coastal States and the oil industry. In addition, following the tragic events of 9/11 the threat of terrorist attack against the maritime infrastructure took on new urgency. Oil tankers and oil related infrastructure such as loading facilities, pipelines, floating storage units, offshore drilling structures are particularly vulnerable to an attack risking the possible shutdown of operations or a massive spill that could create a threat to the global supply of oil.

The sphere of 'security' in maritime matters includes all potential threats to global shipping that could cause significant disruptions and harm to national and global economies. The 'National Strategy for Maritime Security' issued by the White House in 2005 enumerated as maritime security threats: (1) nation-state threats; (2) Terrorist threats; (3) transnational criminal and piracy threats; (4) environmental destruction; and (5) illegal seabourne immigration. ${ }^{1}$

The current lack of spare capacity for crude oil has intensified the need to ensure global security of uninterrupted and reliable oil supply. In this regard, there are two main threats to the secure supply of oil from the Black Sea and Turkish Straits to global markets: accidental disruptions and intentional disruptions. This paper will address existing measures to minimize these threats and propose additional measures that, in the author's opinion, should be adopted to further ensure the security of oil and natural gas supply from the Black Sea region.

\section{The overall energy picture for the Caspian-Black Sea region}

The Caspian region, since 1992, has developed into a major global hydrocarbon region. Kazakhstan stands as the hydrocarbon giant for the Caspian. Its proven reserves are between a low of 9 and a high of 40 billion barrels with even a much greater potential. ${ }^{2}$ In 2004, Kazakhstan exported one million bbl/day but hopes to increase this amount to 3.5 million bbl/day by 2015 . Second to Kazakhstan is Azerbaijan with estimated proven reserves of oil 7-17.5 billion barrels. ${ }^{3}$ Overall, Russian oil reserves rank eighth globally with 60 - 68 billion barrels (International Energy Outlook, 2006), ${ }^{4}$ however its current proven reserves in the Caspian are low with a potential of 7 billion barrels. However, Russian has the largest reserves of natural gas globally. More important, the bulk of Russian oil is transported from the Black Sea and Turkish Straits to European and Asian markets. ${ }^{5}$ In total, proven oil reserves for the Caspian Sea range between 17-44 billion barrels. ${ }^{6}$

The main oil fields in the Caspian are the 'Azeri-Chirag-Guneshli' field (Azerbaijan), estimated to hold proven reserves of 5.4 billion barrels of oil or according to recent reports by

\footnotetext{
${ }^{1}$ http://www.whitehouse.gov/homeland/4844-nsms.pdf

${ }^{2}$ http://www.eia.doe.gov/emeu/cabs/Caspian/Oil.html

${ }^{3}$ Estimates vary according to sources the higher values provided by SOCAR the Azeri State oil company.

${ }^{4}$ United States Dept. of Energy and http://www.eia.doe.gov/emeu/cabs/Russia/Oil.html

${ }^{5} \mathrm{http}: / /$ www.eia.doe.gov/emeu/cabs/Russia/Oil_exports.html

http://www.eia.doe.gov/emeu/cabs/Caspian/Oil.html Previously the EIA estimated between 11-33 bb.
} 
SOCAR 6.9 billion barrels. ${ }^{7}$ The 'Tengiz' oil field (Kazakhstan), which is considered to be one of the world's largest fields and estimated to have 6-9 billion barrels of recoverable oil ${ }^{8}$; 'Karachaganak' (Kazakhstan), which is located onshore in northern Kazakhstan, is estimated to hold 2.4 billion barrels of proven reserves of oil ${ }^{9}$ and 16 Tcf of gas; and Kashagan (Kazakhstan), the largest oil field in the Caspian region and ranked as one of the biggest oil discoveries in the past 34 years, is the world's fourth or fifth largest oil field with total proven reserves of 7-9 billion barrels of recoverable oil. ${ }^{10}$

\section{Modalities of transport of oil}

\subsection{Shipping}

The logistical challenge for the transport of Caspian and Russian oil is simple: there is a significant quantity of oil and gas that needs to be shipped through environmentally sensitive and risky marine areas. The environmental degradation of the Black Sea is a serious concern for the potential damage that an oil spill could cause. NATO and the EU recognized the impact of an oil spill in the Black Sea as an environmental security risk. Most of Caspian oil is transported over sea in tankers.

An additional challenge is presented by the narrow and high-risk waterways of the Turkish Straits, which form a classic chokepoint. Oil from the Caspian region that is transported southbound from the Black Sea must pass through the environmentally precarious Black Sea and the narrow and dangerous Turkish Straits. The Turkish Straits comprised of both the Strait of Istanbul and the Strait of Çanakkale are well known for being high-risk waterways. The risks are attributable to the geomorphology of the Straits and weather factors. The Istanbul Strait measures $31 \mathrm{~km}$ in length and is characterized with twelve sharp bends, one of which is 80 degrees. The narrowest channel of the Strait is 700 meters (approximately 700 yards). Strong currents further add to the navigational risks. Furthermore, in winter time in particular, the weather factor is an important element in the navigational risk factor as well as one of the primary reasons for the delay of ship movements.

In less than ten years the total volume of oil and the number of tankers carrying the oil across the Black Sea and through the Turkish Straits have more than doubled. In 1996 a total of 96 mta of oil and products crossed the Turkish Straits from the Black Sea. In 2005 the amount was nearly $145 \mathrm{mta}$. In 1996 a total of 4,500 tankers (10-12 tankers a day) engaged in passage through the Turkish Straits. In 2005 that number had increased to 10, 023 tankers.

\footnotetext{
${ }^{7}$ http://www.eia.doe.gov/emeu/cabs/Azerbaijan/Oil.html

8 http://www.chevrontexaco.com.

${ }^{9} \mathrm{http}: / / \mathrm{www} . c h e v r o n t e x a c o . c o m . ~ K a r a c h a n a g a k$ also holds a large natural gas field.

${ }^{10} \mathrm{http}: / /$ www.eia.doe.gov/emeu/cabs/kazak.html
} 


\subsection{Black Sea ports and oil pipelines}

Currently, Russia's southern ports handle a majority of its overseas trade. The main ports in the Black Sea for the export of oil are Novorossiysk, Tuapse, Odessa, Supsa, and Batumi. The Black Sea port of Novorossiysk, one of the 10 largest in Europe, has seen a steady increase in export of FSU oil: 49,664,8 mta in 2004; 47,680 mta in 2003; 47,700 mta in 2002, and $44.3 \mathrm{mta}$ crude in $2001^{11}$ and 40,250,00 in 2000. Overall FSU oil export from the Black Sea has increased from $1.53 \mathrm{mbd}$ in 1999 to $3.14 \mathrm{mbd}$ in 2004 . $^{12}$ The total amount of production is expected to increase approximately to $211 \mathrm{mta}$ by 2010 with $154 \mathrm{mta}$ actually going through the Black Sea and Turkish Straits. ${ }^{13}$

Before the oil can be shipped onto tankers most of it is transported by pipelines from the oil fields to ports in the Black Sea and loaded onto tankers. Prior to the collapse of the former-USSR, the Soviet Union had single-handedly controlled energy development in a region that is now represented by three independent states-Azerbaijan, Turkmenistan, and Kazakhstan (Becker, 1998). All oil and gas recovered from Soviet Caspian fields were shipped north to Russia and did not rely on the Black Sea-Turkish Straits route. However, after 1991, as the NIS countries emerged conversely Russia lost its monopoly over oil and gas in the region (Becker, 1998). Moreover, as foreign oil companies began to invest billions of dollars in both infrastructure and cash, the question of market access gained urgency.

The first of these new pipelines to be constructed was the Caspian Pipeline Consortium (CPC) pipeline. In 2001 a consortium of oil companies ${ }^{14}$ commissioned a pipeline with a marine terminal along the Russian coast of the Black sea to transport Tengiz and other Kazakh oil. The initial transport capacity of $22 \mathrm{mta}$ was reached by mid-2004. ${ }^{15}$ Two phases of expansion were planned: the first in 2005 would expand the capacity to $38 \mathrm{mta}$ and the second in 2008 expand the capacity to $48 \mathrm{mta}^{16}{ }^{16}$ However, the current plans are to further expand capacity to $67 \mathrm{mta}$, significantly more than originally planned. Expansion of the CPC to $67 \mathrm{mta}$ would amount to the equivalent of 750 Suezmax tankers per year. ${ }^{17}$

\footnotetext{
${ }^{11}$ Refer Zhannikov (2002)

${ }^{12} \mathrm{http}: / /$ www.eia.doe.gov/emeu/cabs/Russia/Oil_exports.html

${ }^{13}$ Refer Landin (2003), according to whom the Baku-Ceyhan-Tiblisi pipeline will relieve sea transportation burden by 51 mta.

${ }^{14}$ The "Caspian Pipeline Consortium" members were: Russia (24\%), Kazakhstan (19\%), Chevron(15\%), Lukarko (12.5\%), Mobil (7.5\%), Rosneft-Shell (7.5\%), Oman (7\%), British gas (2\%), Adjip (2\%), Oryx (1.75\%), Kazakoil/ Amoco (1.75\%). See http://www.cpc-ltd.com/

${ }^{15}$ http://www.cpc.ru/portal/alias!press/lang!en-US/tabID!3357/DesktopDefault.aspx (Last visit 09.11.2006)

${ }^{16}$ The IEA Black Sea Energy Survey stated that the second phase of expansion for the CPC would be $67 \mathrm{mta}$. It appears that the planned capacity expansion has been reduced.

${ }^{17} \mathrm{~A}$ Suezmax is a tanker designed so that its maximum size by virtue of its draught is able to transit the Suez Canal. $\mathrm{R}$. Gardine (1992) p. 204
} 
Table 1

CPC pipeline oil volume ${ }^{18}$

\begin{tabular}{l|l}
\hline 2005 & 30.502 million tons \\
2004 & 22.512 million tons \\
2003 & 14.778 million tons \\
2002 & 11.131 million tons \\
2001 & 933 thousand tons \\
\hline
\end{tabular}

A second post-USSR pipeline constructed along the Black Sea coast in 2002 is the 674 kilometer Odessa-Brody pipeline with a 14.5-45 mta capacity and is also the first of the EU Inogate pipeline projects. The project was originally designed to link oil supplies from the Black Sea to the oil refinery in Plock Poland was eventually extended to the Baltic Sea port of Gdansk, Poland, in 2004. However, that same year a decision was taken by Russia to reverse the flow of the pipeline resulting in bringing more oil ( 9 mta for three years) into the Back Sea, and consequently through the Turkish Straits.

The most recent pipeline to be completed for the transport of Caspian oil is the Baku-TblisiCeyhan pipeline (BTC), 1,768 km in length. It transports oil from Baku (Azerbaijan) and Tblisi (Georgia) to Ceyhan, a port on the Turkish Mediterranean coast (Oral, 2001). ${ }^{19}$ The BTC pipeline will transport up to $50 \mathrm{mta}$ of oil when fully operational (BBC News, 2005). ${ }^{20}$ In March 2005, Kazakhstan and Azerbaijan agreed to build the Aktau-Baku pipeline, connecting the Kashagan offshore oil fields near Aktau in Kazakhstan to the BTC in Baku via a sub-Caspian in 2008. The Kashagan field is expected to produce 1.2 million bbl/day by 2016 , when $600,000 \mathrm{bbl} /$ day of its production is to be shipped across the Caspian Sea to be fed into the BTC line.

The historic 'BTC' pipeline project began operations in June 4th 2006 when the first tanker was loaded with Azeri oil. ${ }^{21}$ The BTC is a significant development in the region for a number of reasons: it is the first pipeline in which the Russian Federation does not have an involvement; it is the longest pipeline project of its kind; it completely by-passes the Black Sea and the Turkish Straits relieving these environmentally vulnerable marine areas from the ecological risks of oil transportation.

Another is the 'Burgaz-Alexandroupolis' (Transbalkan pipeline) pipeline, which is favored by the Russian Federation. It would transport oil from the Bulgarian Black Sea port of Burgaz to the Aegean port of Alexandropoulis. At a recent meeting held in Athens the heads of State of Russia, Greece and Bulgaria agreed to go forward with the $280 \mathrm{~km}$ and 700 Euro project.

Similar grand projects were developed for the transport of natural gas. The 'Blue Stream' project, which was inaugurated in 2005 , is a $1,250 \mathrm{~km}$ pipeline with the capacity to transport 16

\footnotetext{
${ }^{18}$ Data based on information from http://www.cpc.ru/portal/alias!press/lang!en-US/tabID!3369/DesktopDefaultaspx

${ }^{19}$ Refer also, Plant (2000); Plant (1995); Soligo et al. (1999); Hicks (1998); Scharfenberg (1996).

${ }^{20}$ The BTC is the longest pipeline built measuring 1,768 kilometers in length at a cost of US\$3.6 billion. http://www.caspiandevelopmentandexport.com

${ }^{21}$ The official inauguration held on 13 July 2006 in Ceyhan.
} 
billion cubic meters of natural gas from Russia (Izobilonoye) to Turkey (Ankara) with 235 miles of the pipeline stretched across the floor of the Black Sea. Another pipeline to follow a parallel route to the BTC for the transport of natural gas, the 'South Caucasus' pipeline (Baku-Tblisi-Erzurum), is also being developed.

\section{Security risks}

As previously mentioned there are different types of security risks to marine transport including environmental risks and terror risks. Both the Black Sea and the Turkish Straits are potentially vulnerable in both of these. The Black Sea is one of the most environmentally degraded regional seas having suffered from decades of land-based pollution as well as non-sustainable fishing practices. As a consequence, it is vulnerable to any additional input of pollution, such as an oil spill. Likewise, the Turkish Straits, which receive Black Sea-source pollution, local land-based pollution, and vessel-source pollution, form approximately 55,000 ships annually.

Furthermore, the security of oil and natural gas, that is, ensuring the uninterrupted and steady supply of these two vital energy resources to global markets is a primary concern. The importance of oil and natural gas transport security in the Black Sea and the Turkish Straits has become more pronounced in the past two years as the spare capacity of oil at the global level has diminished significantly which as in turn increased the vulnerability of global markets to any disruption of supply. Such seemingly benign factors such as poor weather conditions causing delays in the passage of oil tankers from the Black Sea through the Turkish Straits as experienced in the winter of 2004 demonstrated the vulnerability of global oil supply to such disruptions. More important however, is the potential risk of terrorism and conflict (war) particularly in light of recent events in the Middle East. The possibility of an oil facility, an oil tanker or related infrastructure falling prey to an attack is beyond theory as such attacks have taken place.

NATO, in 2001, specifically identified environmental security in the Black Sea as being of 'great importance' because of the 'appreciable amount' of oil and gas resources planned to be produced and transported from the Caspian Region and the Black Sea Region (NATO Report: 2001). The NATO Report concluded that this requires "environmental security be given special attention" because of the sensitivity of the Black Sea to pollution loads, and that "cooperation and joint efforts of source, transit and end user countries are considered to be vital."

The EU Green Paper on Energy (COM, 2006) also recognized that in securing energy supplies, environmental protection against damage caused either by accidental factors such as shipping accidents or by polluting emissions could cause disruptions in the energy supply chain. Such 'disruptions' would necessarily constitute a serious 'energy security' concern. On May 13, 2003 the EU issued a Communication entitled "the Development of Energy Policy for the Enlarged European Union, its Neighbours and Partner Countries." (COM, 2003) The objectives of the policy outlined in the Communication include enhancement of the security of energy supplies 
of the European continent, 'security' with two elements: physical and commercial. ${ }^{22}$

The Communication underscored the broad reach of Europe's energy policy to include neighbouring countries to the European Union as having a 'vital role' in the Union's energy policy. (COM, 2003: 4) It is important to note that the Communication specifically mentioned 'maritime safety' as a principal issue to be addressed for security of energy supply with regard to oil. (COM, 2003: 5)

The Communication did specifically address the energy security issues regarding the Caspian Basin, noting that the "key will be to facilitate the transportation of Caspian resources towards Europe, be it via transit through Russia or other transport routes. Indeed, secure and safe export routes for Caspian oil and gas will be important for the EU's security of energy supply as well as crucial for the development...of the Caspian Region.” (COM, 2003: 12)

In addressing the issue of oil, it is important that the Commission made detailed reference to the Erika and Prestige maritime accidents as a reason that the EU should engage in concerted action between the EU and neighbour countries to "ensure the highest possible safety standards for the maritime transportation of oil." (COM, 2003: 26) ${ }^{23}$ These two maritime accidents demonstrated the vulnerability of marine transportation and the threat against security of energy that such incidents could pose. Furthermore, the increased tanker traffic in the Black Sea and Turkish Straits were also identified as reasons for increased co-operation with neighbouring countries to enhance the safety and security of maritime transportation of oil in response to the Prestige accident. ${ }^{24}$

\subsection{Risks created by accidental factors in the Black Sea and Turkish Straits}

The Black Sea, remarkably, has not experienced the magnitude of accidents that have left their mark in maritime history, such as the Titanic (1912), the Torrey Canyon (1967), the Independenta (1979), the Exxon Valdez (1989), the Erika (1999) and Prestige (2002). Nevertheless, so long as ships ply its waters, and often ships of questionable shipping quality, the risk of an accident shall continue. Given the heightened degradation of the Black Sea marine environment precautions must be taken to both prevent maritime incidents and to be prepared to respond in the case of one occurring, especially for dangerous and hazardous substances.

Some recent examples of maritime incidents in the Black Sea include the collision that occurred on 2 May 2003 between the 160,000 dwt Suezmax, Nuria Tapia, with the 83 gwt Junior $M$ just 75 miles from the Turkish coastal city of Sinop. The Nuria Tapia was in ballast en route to Novorossiysk. The Junior M. sank after the Nuria Tapias was able to rescue all 20 of its crew. ${ }^{25}$ Another tragic accident took place on February 13, 2004, during a storm when the Cambodian flagged and Bulgarian owned Hera sank in the Black Sea resulting in the loss of its crew of

\footnotetext{
${ }^{22}$ The Commission expressly recognized these two elements of security. Para. 7.1.

${ }^{23}$ The Commission stated that due to "the increased density of maritime traffic in the waters around the EU, it is of utmost importance to give a higher priority to considering...the alternative of transporting oil by pipelines..."

${ }^{24}$ The Commission included suggestion for upgrading and expanding existing pipelines as well as building new ones. http://aei.pitt.edu/archive/00000493/01/chai36e.html\#N_1_

${ }^{25} \mathrm{http}: / /$ www.turkishpilots.org
} 
nineteen men and a cargo of coal. ${ }^{26}$ On the same day, during the same storm, the Korean flagged Lujin I with its 16 crewmembers and the Russian flagged Strontsiy with its eleven crewmembers were grounded in the Strait of Istanbul.

The Turkish Straits, on the other hand, have experienced many more accidents, including several major accidents involving oil tankers. The most serious of these took place in 1979 when the Independenta a tanker carrying 96,000 tonnes of crude oil collided with the Shipbroker, a dry cargo vessel causing one of worst oil spills on record. The Independenta accident has been ranked eleventh in terms of the volume of oil spilled. Forty-three crewmembers tragically died in a fire that burned for weeks and 96,000 tonnes of crude oil spilled in to the sea and burned into the air. A similar collision took place in 1994 when the Nassia collided with the Shipbroker in the Strait of Istanbul.

On 12 March 2005, during a storm a Ro-Ro ferry carrying seven LPG loaded lorries sank causing the lorries to be swept by the fierce currents creating a very imminent danger to the surrounding area. Luckily, the Turkish Coastal Safety and Salvage rescue team was able to secure and retrieve the LPG tankers quickly. Shortly thereafter, on 2 April 2005 a fatal collision in the Straits of Çanakkale left three crewmembers dead.

Most recently, the Strait of Istanbul narrowly escaped a disastrous accident involving a fully laden oil 243 meter oil tanker. On 21 February 2006 a carrying 86,000 tonnes of fuel oil while navigating through the Istanbul Strait at a speed of $12 \mathrm{~nm}$ experienced rudder failure and missed ramming the into $18^{\text {th }}$ Century Dolmabahçe Palace by 200 meters.

The concern shared by interested parties is that a serious incident resulting in another oil spill could force the Turkish government to suspend passage through the Straits for an indefinite period of time, especially if there is strong public opposition to continued oil transportation activities. A temporary abeyance of passage of oil, even for one week could have significant repercussions for available oil and consequently on the economies of affected countries.

In addition to accidents severe weather conditions, such as snowstorms and fogs have also resulted in extensive delays for ships. In the winter of 2004 the city of Istanbul experienced one of its harshest winters. Winter storms sank two ships on the same day. The Strait of Istanbul had to be closed to passage for vessels.

\subsection{Risks created by intentional factors}

In 2004 a ship carrying 19 tonnes of undeclared explosives was discovered in the Turkish Straits only after it had grounded in the Straits of Çanakkale. Such incidents acquire enhanced importance especially recalling that just one year before September 11 the USS Cole, a US military ship was attacked by a small zodiac boat just off the coast of Yemen on 12 October 2000. Two years following the USS Cole incident a similar attack took place against a French oil tanker, the 332-meter long Limburg, while in the Port of Mina al-Dabah in Yemen. Both attacks involved the use of small boats, loaded with explosives, ramming into the targets. Furthermore, similar to the Lauro Achille hijacking incident off the coast of Egypt that resulted in the death of one American

\footnotetext{
${ }^{26}$ Refer Oral and Mitchell (2005). www.turkishpilots.org/DOCUMENTS/N_Oral_Recent_Accidents.html
} 
citizen an armed group of Chechen terrorists had hijacked a ferryboat in the Turkish territorial waters of the Black Sea. Fortunately, no one was harmed, but the even demonstrated the vulnerability of shipping to acts of terror.

Pipelines are also vulnerable to intentional disruptions, as has been the case with the pipelines from Iraq to Turkey (Yumurtalik-Ceyhan) and the recent sabotage attempt against the newly operational BTC pipeline.

\section{Measures for enhancing security}

\subsection{Threats to the security of oil transport based on accidental factors}

\section{Traffic management}

To address the growing risk of shipping accidents in general, and that related to the transport of dangerous or hazardous cargo the Turkish government undertook significant reform by introducing a new set of maritime traffic regulations in 1994, later amended in 1998; introducing a traffic separation scheme for the Turkish Straits that was approved by the IMO, and establishing a multi-million dollar state-of-the-art vessel traffic system. In addition, the IMO, adopted resolution A.827(19) Rules and Recommendations on Navigation through the Strait of Istanbul, the Strait of Çanakkale and the Sea of Marmara (IMO Rules and Recommendations) which in addition to adopting the TSS mentioned above, also exhorted for ships navigating through the Turkish Straits to engage a pilot. Furthermore, the resolution in many ways paralleled the Turkish Straits regulations. The IMO Rules and Recommendations supported the Turkish Straits ship reporting requirements as provided for in the Regulations as well as the suspension of traffic for the passage of ships carrying dangerous or hazardous cargo. ${ }^{27}$

\section{Accidental vessel source pollution and oil spill response}

All six of the Black Sea coastal States are members of the International Maritime Organization (IMO). However, of the six, Russia and Turkey constitute the major shipping powers, as the only two countries to be listed in the UNCTAD 35 most important maritime countries, with

\footnotetext{
${ }^{27}$ Specifically, the Rules and Recommendations require vessels shall exercise full diligence and regard for the requirements of the traffic separation scheme (1.1). Those vessels not able to comply with the TSS shall give advance notice. The Turkish administration is authorized, then, to temporarily suspend two-way traffic and regulate one-way traffic to maintain a safe distance. Ships are in these circumstances advised to abide by Rule 9 of the International Regulations for Preventing Collisions at Sea, 1972 (1.2 and 1.3). Ships are strongly recommended to participate in the Turkish ship reporting system (TÜBRAP) (2.1) and are strongly advised to provide information about their characteristics and cargoes (2.2). Transiting ships are strongly advised to use a pilot (3.1) and vessels having a length of more than 200 meters and a draught more than 15 meters are advised to navigate the Straits in daylight (4.1). Recommendations are also made for towing and anchorage (5.1 and 6.1).
} 
Russia ranking 14th and Turkey 17th (UNCTAD, 2003, 33). The overall participation by Black Sea littoral states to IMO Conventions is intermediate and could be improved. Specifically in regards to oil pollution, there are problems related to the effective implementation of the MARPOL $73 / 78$ particularly for illegal discharges of oil and oily substances in violation of the special area designation of the Black Sea. Another important area requiring improvement is for adequate reception facilities in Black Sea ports.

In relation to oil spill response, although slow in its development the Black Sea countries both individually and regionally are making progress. Oil spill preparedness in the Black Sea was also one of the main commitments undertaken by the Black Sea States under the Bucharest Convention and then, specifically, the Odessa Declaration. According to the latter, by 1996, national and regional contingency for combating pollution in emergency situations were to have been developed. ${ }^{28}$ However, due to institutional problems and delays this date was not met (Ǿstergaard, 2004). In 2002, these commitments were reaffirmed after the 1996 BS-SAP had been amended with new benchmark dates. In 2003, under the aegis of the Black Sea Commission, a Black Sea Contingency Plan was adopted but has not yet entered into effect. The Contingency plan is divided into two parts: the first part addresses response oil spill and the second part addresses response to harmful substances other than oil. ${ }^{29}$

Although all six of the Black Sea countries have a draft national contingency plan, only Russia, Bulgaria and the Ukraine have actually adopted a National Contingency Plan (NCP). ${ }^{30}$ There has, however, been close cooperation between the IMO and the Black Sea countries, including training exercises conducted at the CPC oil terminal. Nevertheless, the Black Sea is ranked 'high' for oil spill risk and 'low' for oil spill preparedness (ITOPF).

\section{Substandard vessels}

The Black Sea States signed the Black Sea Memorandum of Understanding (BS MoU) in 2000 agreeing that the Secretariat be located in Istanbul. According to the BS MoU each state is to inspect at least $15 \%$ of the vessels calling at port. ${ }^{31}$ There are a total of 45 Black Sea MoU inspection ports. (BSMOU, 2005) ${ }^{32}$ Of these 20 are located in the Ukraine, 7 in Bulgaria, 7 in Romania, 5 in Turkey, 4 in the Russian Federation and 2 in Georgia. The detention records published by the BS MoU reflect a significant number of vessels navigating the Black Sea that fail to meet international standards. However, the Black Sea MoU has not adopted a list of banned vessels as is the case with the Paris MoU.

In 2003 a total of 5,228 port state control inspections were conducted of which 16,773 total deficiencies were found. Of these $11.73 \%$ were related to safety of navigation. In 2004 of a total of 5,653 port state control inspections $61.83 \%$ were found to have deficiencies of which $11.48 \%$ were related to safety of navigation. In 2005, a total of 5,069 ships were inspected of which $62.93 \%$ were

\footnotetext{
${ }^{28}$ Article 11 .

${ }^{29}$ The contingency plan for harmful substances other than oil is currently being developed

${ }^{30} \mathrm{http} / / / \mathrm{www}$.itopf.com/country_profiles/index.html.

${ }^{31}$ Turkish Republic Official Gazette No. 24258 (12 December 2000)

${ }^{32} \mathrm{http}: / /$ www.bsmou.org
} 
found to have deficiencies (BSMOU, 2005).

Nevertheless, the Black Sea MoU is making advancements. For example, it will be adopting on a trial basis a ship targeting system and has also begun to cooperate with the MED MoU. ${ }^{33}$ Furthermore, in 2005 the Black Sea PSC Committee granted observer status to the United States Coast Guard, the Permanent Secretariat of the Black Sea Commission and the West and Central African MoU Secretariat. The Black Sea PSC Committee also applied to the IMO Secretary General for status as an inter-governmental organization to allow direct participation in IMO activities and report directly to relevant IMO bodies. Another important decision taken by the Committee was to introduce on a trial basis a computer based ship targeting system and publication of a shipping black list as done by the Paris MoU.

\subsection{Surveillance and Monitoring}

A web of coordinated electronic vessel traffic systems (VTS) is being developed throughout the Black Sea, including the Turkish Straits, creating an important component for surveillance and monitoring of ships navigating in the Black Sea and Turkish Straits and enhancing situational awareness and operating as a potential deterrence tool as well (Hofstee, et al., 2004). ${ }^{34}$ There are several VTSs in the Ukraine and the Russian Federation. In 2001, a VTMIS in Constanza Romania was established. The land-based radar sites will provide position locations of all vessels in the Constanza Port area and the Danube-Black Sea area. There is also a VTS in Georgia and in Bulgaria. The latest addition in the Black Sea region was the state-of-the-art multi-million dollar electronic VTMIS established in the Turkish Straits which has operational since 1 January 2004.

Regional security for the transport of oil across the Black Sea will require close cooperation among the coastal States, which means sharing of information collected from radar and satellite surveillance. The existence of a regional web of VTS systems is an important component of surveillance and when needed tracking of suspect vessels in the Black Sea.

Additional aids to and the surveillance monitoring of vessels for security purposes are the automated identification system (AIS), continuous synopsis ship reporting (CSR) and the long range identification and tracking of ships (LRIT). The AIS and CSR were made mandatory for the implementation of the ISPS Code. AIS stations are being established throughout the Black Sea. The Russian port of Novorossisky, a key oil loading terminal already has established an AIS system.

The $81^{\text {st }}$ session of the Maritime Safety Committee of the IMO in May 2006 agreed to make the LRIT mandatory for certain categories of ships, that would include oil tankers 300 gt and over and mobile offshore drilling units. ${ }^{35}$ Coastal States will be entitled to receive LRIT data from ships up to $1000 \mathrm{~nm}$ from their coasts and based upon a multilateral agreement to share information internationally for security and search and rescue reasons, subject to existing rules of international law.

\footnotetext{
${ }^{33}$ Seventh Meeting of the Black Sea MOU Port State Control Committee, Press Release. http://www. bsmou. org/ default2.htm

${ }^{34}$ Refer also, Molenaar et al. (2000).

${ }^{35}$ Once adopted by the IMO General Assembly the new regulation on LRIT will be part of SOLAS Chapter V on Safety of Navigation and is expected to become applicable as of 1 January 2008.
} 


\section{The Turkish Straits}

The responsibility for providing the safety and security of oil transport security in the Turkish Straits is shared between the Turkish Coastal Guard Command (CGC), the Ministry of Forestry and the Environment, and the Turkish Maritime Undersecretariat together with the General Directorate of Coastal Safety and Salvage (CSS). In general, the Turkish CSC has wide responsibility for the enforcement of the Turkish Environmental Protection Code in marine areas falling within Turkish national jurisdiction. On the other hand, the responsibility for regulating shipping in Turkish waters, including the Turkish Straits is under the purview of the Ministry of Transportation and the Undersecretariat for Maritime Affairs (Undersecretariat). The Undersecretariat and the CSS are directly responsible for providing for safety of navigation in Turkish waters and in implementing many of the preventative measures, such as the VTS and the 1998 Turkish Straits Maritime Traffic Scheme Regulations (1998 Regulations) in the Turkish Straits. ${ }^{36}$ The responsibilities in the case of an oil spill in Turkish waters are shared between the Ministry of Forestry and the Environment, the Under secretariat and the CGC, the latter having exclusive responsibility for policing and security. ${ }^{37}$

Overall transport security in the Turkish Straits is provided by a system of ship reporting and ship monitoring together with special rules of passage for tankers carrying dangerous or hazardous cargo. The 1998 Regulations, the VTMIS User Guide, ${ }^{38}$ and the Administrative Guidelines for the Turkish Straits cumulatively provide the detailed rules of passage for all ships, including those carrying dangerous and hazardous cargo.

The 1998 Regulations were adopted primarily to ensure safety of life, property and protection of the marine environment of the Turkish Straits. However, it does not address the sensitive subject of potential terror attacks. Nonetheless, the 1998 Regulations indirectly provide for some preventative measures against potential terror attacks. The main tool is a ship reporting system that requires ships carrying dangerous or hazardous cargo to report at least 72 hours in advance of their arrival and to provide information as the cargo being transported, IMO certificates, and planned voyage schedule. ${ }^{39}$ This same requirement was incorporated into the VTMIS Guidelines.

Otherwise, the 1998 Regulations make only one express reference to security and that is found in Article 38 (Istanbul Straits) and Article 46 (Çanakkale Strait) regarding inspection and boarding rights of ships while engaged in passage in the traffic separation schemes. These two articles, identical in language, prohibit boarding and inspection for customs and security reason when the ship is navigating within the TSS unless there is a cause in which case the inspectors are to board ships at pilot embarking locations.

The Turkish Straits Vessel Traffic and Information System (TSVTS) has been fully operational since 2004. While its primary purpose is to enhance the safety of navigation in the

\footnotetext{
${ }^{36}$ Official Gazette no.23515 of 6 November 1998. Under the law the CSS has exclusive right to establish and operate the VTS in the Turkish Straits.

${ }^{37}$ Law no. 5312 Adopted 3 March 2005, Official Gazette 25752

${ }^{38} \mathrm{http}: / /$ www.coastalsafety.gov.tr/

${ }^{39}$ Article 26
} 
Turkish Straits, it can also play an important part in providing for enhanced security for transport of dangerous cargo, such as oil and oil products. The TSVTS is a multi-million dollar state-of-the-art radar based VTS. It provides for real time surveillance of the Turkish Straits and on-going communication with ships. Within its coverage area the TSVTS uses radar, ENC, AIS, CCTV and VHF equipment such as VHF R/T, DSC and DF. The TSVTS also receives information from various sources on anticipated vessel movements, hazards to navigation, aids to navigation and any other information of interests to TSVTS participants.

Turkey, as a candidate court for membership to the European Union is also undergoing reformation of its laws, including its maritime related laws to be consistent with EU acquis. One of the recent directives adopted by the EC instituted a mandatory ship report reporting system. (2002/59/EC) Ships intending to enter EU ports are required to provide certain information at least 24 hours in advance. Furthermore, ships transporting hazardous cargo have to deliver a declaration containing certain information.

The Administrative Guidelines to the 1998 Regulations instituted in 2000 are intended to provide to the traffic control centers guidelines to implementing the 1998 Regulations. These guidelines provide for daylight passage for vessels carrying dangerous or hazardous cargo, as well as the criteria for one-way or two-way suspension of traffic and when tug escorts and pilots should be employed by these vessels.

Notwithstanding military measures, which are beyond the scope of this paper, the legal framework for the passage of ships transporting oil as cargo in the Turkish Straits is directed primarily towards providing for safety of navigation and protection of the marine environment. Precautionary measures against possible external intentional disruption of oil movement through the Turkish Straits are only a by-product of the existing rules and regulations. The question is whether there is a need to further supplement the existing 1998 Regulations and TSVTS Guidelines with security specific provisions, particularly with the adoption of the amended SOLAS Chapter XI-2 and the ISPS Code, which is discussed below.

\section{Measures taken against intentional causation}

\subsection{SOLAS Chapter XI-2 and the International Shipping and Port Security Code (ISPS Code)}

SOLAS chapter XI -2 and the ISPS Code were adopted as a direct response to the tragic events of 11 September 2001, 9/11 attacks. The ISPS Code marks the first international maritime security instrument that actually provides for means of detecting and preventing potential terror attacks at ports, offshore facilities and ships. It establishes an early risk assessment system with early and efficient information collection, to provide a methodology for security assessment, and finally to ensure confidence that 'adequate and proportionate' security measures are in place.

The ISPS Code, inter alia, requires that ships engaged in international voyage flying the flag of a contracting government and ports used in international shipping must have an approved security plan. Compliance is evidenced with a certificate issued by the government. The Code also provides 
for functional requirements that include gathering and assessing information in respect to security threats, requiring maintenance of communication protocols for ships and port facilities, preventing unauthorized access to ships and port facilities, preventing the introduction of unauthorized weapons and explosives, establishing an alarm alert system in case of a security threat, requiring preparation of security plans for ships and port facilities, and training and drills for their implementation. SOLAS regulation XI-2/11.1 also provides for developing of bilateral or multilateral agreements on alternative security agreements as provided by SOLAS regulation XI2/11.1.

In Turkey, the Undersecretariat is the national designated authority for the ISPS Code. In addition for assuming the primary responsibility of the implementation of the ISPS Code in Turkey, the Undersecretariat also established a permanent ISPS Monitoring Committee with the participation of naval command, the CSC, the CSS and the customs. The primary function of the Committee is advisory. Ship security alerts are directed to the Main Search and Rescue Coordination Center headquartered in Ankara.

The Black Sea States succeeded in meeting the 1 July 2004 compliance date. However, compliance with the threshold requirements of the ISPS Code in and of themselves is not sufficient to provide for the heightened security needs of a security-risk region. Strict application and enforcement of the ISPS Code will require adequate training of port and ship officers. This in turn will mandate that the Black Sea ports must rigorously assess incoming ships for possible security breaches from non-complying ports of departure, as well as assure that Black Sea port facilities used in international shipping continue to meet the standards required by the Code. As an energy strategic region and transport route, with approximately $150 \mathrm{mta}$ of oil transported in 2004, and a sea which has a high number of ships sailing under registries with questionable record of implementing generally accepted international rule and standards for safety, the Black Sea is a high risk area.

Regional cooperation among the Black Sea coastal states is proving to be fruitful. Turkey has conducted bilateral negotiations for concluding bilateral ISPS agreements with the Black Sea coastal states resulting in a draft agreement with the Russian Federation ${ }^{40}$ and Romania. ${ }^{41}$ Once adopted, the Port Masters will be in direct communication with each other providing important information such as the departure of ships transporting dangerous or hazardous cargo. The Black Sea States are working towards a strong integrated system of coordination, information sharing and cooperation for enhancing security of shipping in the Black Sea and the Turkish Straits. It should be noted that transnational pipelines used for the transport of oil or natural gas are not within the scope of coverage of SOLAS chapter XI-2 and the ISPS Code does not include within their purview.

\footnotetext{
${ }^{40} \mathrm{Based}$ on conversation with Turkish Maritime Undersecretariat the draft agreement is currently being reviewed by the Russian authorities.

${ }^{41}$ According to information provided by the Turkish Maritime Undersecretariat the agreement has been approved in principle by both parties and is awaiting final adoption.
} 


\subsection{BlackSeaFor}

The Black Sea coastal states created an historic alliance on 2 April 2001 with the signing of the 'BlackSeaFor Establishment Agreement." 42 The six Black Sea countries established a joint naval alliance whose purpose has been expressly defined to be non-military in character. Its stated purpose is to enhance peace and stability in the Black Sea and to increase regional cooperation. This regional 'task force' was not intended to be a traditional military alliance. ${ }^{43}$ Rather, it was intended "to contribute to the further strengthening of friendship, good relations and mutual confidence among the Black Sea littoral states as well as to improve peace and stability in the region, through the enhancement of co-operation and interoperability among the naval forces." Its tasks include environmental protection operations ${ }^{45}$ as well as combating terrorism and organized crime. In March 2005, the force's mandate was extended to include the fight against terrorism and proliferation of weapons of mass destruction (WMD).

One of the technological advancement developed by Turkey for the BlackSeaFor operations is the PC-to PC secure communication systems. ${ }^{46}$

\subsection{Black Sea Harmony}

The Black Sea Harmony (OBSH) naval operation was initiated by Turkey in March 2004 in accordance with UN Security Council Resolution 1373. It is a parallel operation to the NATO-led Operation Active Endeavour in the Mediterranean Sea, although currently it is active only in Turkish national waters, it is expected to become a Black Sea regional force with the participation of the other Black Sea coastal states. Its objective is to protect Turkish Black Sea waters and the Turkish Straits against worldwide terrorism and WMD. The mission of the OBSH includes to (Gürdeniz, 29)

- Conduct periodic maritime and aerial surveillance operation

- Conduct reconnaissance operations for suspect vessels

- Trail or shadow suspect vessels

- Show naval presence in maritime shipping routes

The OBSH conducts an assessment of ships based on ship reporting information and will shadow suspect ships and furthermore, if clear grounds exist together with credible intelligence that a vessel is involved in illegal activities in the Black Sea, when in Turkish territorial waters, for example, will notify the Turkish Coast Guard who will then proceed with conducting ship boarding procedures. In 2005 over 200 port visits were conducted on board suspect ships in Turkish ports. The objective is to turn the $\mathrm{OBSH}$ into a multinational operation with the

\footnotetext{
${ }^{42}$ The Agreement went into effect in 2001 upon the final ratification of Russia. See http://www.blackseafor.org/

${ }^{43}$ Article II (2).

${ }^{44}$ Article IV (1).

${ }^{45}$ Article IV(2)(d)

${ }^{46}$ Refer Gürdeniz (Provided by author).
} 
cooperation of all six Black Sea coastal states and for it to become absorbed by BlackSeaFor. In 2005 the Ukraine and Russia agreed to join with OBSH.

\section{EU-Russia energy dialogue}

With its vast supply of oil Russia stands out as a major energy producing country for the EU countries, major consumers of Russian oil. ${ }^{47}$ Recognizing the importance of Russian oil the EU initiated the EU-Russian Energy Dialogue, whose purpose is to enhance cooperation on energy matters between the EU and Russia.

It was at the EU-Russia Summit of November 2003 that the parties expressly addressed the issue of enhancing cooperation in safety of maritime transport of oil as an issue of security of transport networks. The Fourth Progress Report issued after the meeting noted the necessity "to ensure the maximum possible environmental safety levels for the transportation of crude oil and oil products." ${ }^{48}$ For this reason, the parties recognized the importance of infrastructure, handling facilities at oil terminals, and the resilience of maritime tankers in addition to pipeline security. The parties agreed to work together in the short run on measures of maritime safety. The EU-Russian Dialogue website specifically states that the safe and reliable transportation of crude oil and oil products, including transport by rail and sea, is an important sector of co-operation. ${ }^{49}$

However, the main concrete action taken within this Dialogue forum for the enhancement of the security of the transport of oil has been the development of a joint satellite system to be used for maritime navigation surveillance by 2008. The project will combine the Russian Glossnost satellite system with that of the EU Galileo satellite system to create the first global satellite navigation system.

\section{Conclusion}

The Black Sea and the Turkish Straits have become strategic and vital maritime routes for the transport of Caspian oil and natural gas over sea and by pipeline. In less than a decade there has been an significant increase in both the volume of oil and the number of tankers transporting oil across the Black Sea and through the Turkish Straits. The importance of Caspian oil and natural

\footnotetext{
${ }^{47}$ European Union countries obtain $25 \%$ of their oil and $25 \%$ of their natural gas supply from the Russian Federation. See http://www.euractiv.com/en/energy/eu-russia-energy-dialogue/article-150061.

${ }^{48}$ Joint Declaration By S. Berlusconi, President of the European Council, assisted by J. Solana, Secretary-General of the Council/High Representative for EU Common Foreign and Security Policy, R. Prodi, President of the Commission of the European Communities and V.V. Putin, President of Russian Federation, Annex III, EU-Russia energy dialogue Fourth Progress Report. See http://europa.eu.int./comm/external_relations/russia/summit11_03/ 3concl.pdf(Last visit 26 April 2004).

${ }^{49} \mathrm{http}: / /$ www.euractiv.com/en/energy/eu-russia-energy-dialogue/article-150061 (Last visited 04.09.2006)
} 
gas has significantly increased in the past few years which in turn have highlighted the need for ensuring the uninterrupted and reliable transport of these resources to global markets. For this reason both environmental security and physical security of transport against terror attacks are of great importance. The concern for the security of transport of Caspian oil has been expressed notably by NATO, EU and also by the EU-Russian Energy Dialogue.

In response to growing concerns against risks to the secure transport of oil by sea by reason of accidental factors Turkey and the IMO adopted a number of important measures which have significantly decreased the risk of transport, but not eliminated them as demonstrated by recent near - miss incidents. The Turkish Government introduced a new TSS and set of navigation regulations in 1994 including a ship reporting system. The IMO adopted Resolution A.827(19) and the associated "Rules and Recommendations on Navigation Through the Straits of Istanbul, the Straits of Çanakkale and the Marmara Sea" implementing the TSS based on COLREG 10 and the associated rules and measures. Furthermore, in 2004 a sophisticated VTS system was put into operation for the Turkish Straits allowing closer monitoring of ships engaged in passage through the Turkish Straits.

At the regional level, although some advance has been made, there is still more that needs to be done to promote quality shipping and deter substandard shipping in the Black Sea through strengthened port state control and oil spill response. An important outstanding weakness is the lack of implementation of a regional oil spill plan. Furthermore, there is a need to institute a regional emergency response center such REMPEC in the Mediterranean Sea. The Black Sea is considered a high risk area for an oil spill and yet adequate measures have not been taken to respond in case of an oil spill. Further, consideration should be given to developing a regional approach to the important issue of ships in distress and ports of refuge.

In regard to providing for security against potential terror attacks, most of the non-military measures taken are derivative of measures taken to provide for safety of navigation and protection of the marine and coastal environment, especially in the case of the Turkish Straits. The TUBRAP ship reporting system and the VTS provide an important tool for monitoring and surveillance of ships navigating into and out of the Black Sea and Turkish Straits. The regional integration of the Black Sea VTS and AIS systems will provide an important web of surveillance and monitoring critical to detecting and preventing potential attacks against oil tankers. Furthermore, the conclusion of bilateral ISPS Code agreements amongst the Black Sea coastal States furthering information sharing and cooperation will further add to creating a tight security net for shipping in general and transport of dangerous and hazardous in the Black Sea and Turkish Straits.

Furthermore, the OBSH and BlackSeaFor has a great potential for enhancing overall regional shipping security in the Black Sea. OBSH has been an effective tool for intercepting and preventing illegal activities in Turkish territorial waters and especially for the Turkish Straits. Expansion of the operation to include the other Black Sea coastal states will be an important development for securing shipping activities regionally. While the BlackSeaFor holds potential for serving as a regional coast guard it does not yet operate on a permanent basis.

Overall, over the past few years important advancements have been made to enhance the security of oil transportation by sea through the Black Sea and Turkish Straits. Although the threat of a terrorist attack is not considered to be high this does not relieve interested parties and 
stakeholders from adopting all required measures consistent with international law to detect, apprehend and prevent attacks against shipping in general. The risk that remains the highest in the Black Sea for oil transportation relates to environmental risks associated with accidental and operational vessel-source pollution. The Black Sea countries need to continue to improve port state control operations, adopt oil spill contingency planning and conduct regional oil spill response exercises, and establish an oil spill emergency response center.

\section{References}

Becker, A. S. 1998. Russia and Caspian Oil, Moscow Loses Control (Rand).

Gardine, R. ed. 1992. The Shipping Revolution. London: Conway Maritime Press, 204.

Gurdeniz, C. 2005. The Current naval picture. Paper presented at the Maritime Security in the Black Sea Conference held 2-3 November 2005 in Sofia.

Hicks, E. J. 1998. Environmental Constraints on Development of Caspian Oil and Gas Resources: The Bosphorus and Caspian Sea. http:/www.wws. princeton.edu/ wws401c/1998/ emily.html.

Hofstee, R. and O. Poyraz. 2004. Cooperation between Vessel Traffic services (VTSs) in the Black Sea: Nordquist, Myron H., John N. Moore and Alexander S. Skaridov, eds. International Energy Policy, the Arctic and the Law of the Sea Lieden: Martinus Nijhoff 2004. 157.

Landin, K. 2003. Black Sea oil transportation. Paper presented at the Black Sea: Energy and the Environment Conference, Istanbul Bilgi University: 14 May 2003.

Molenaar, E. J. and M. Tsameny. 2000. Satellite-based vessel monitoring systems for fisheries management: International legal aspects. International Journal of Coastal and Marine Law 15, no. 1 (March): 65-110.

Oral, N. Oil and Water. 2001. Caspian oil and transportation challenges facing the Turkish Straits. Nordquist, M. H. \& J. N. Moore, eds. Current Marine Environmental Issues and the International Tribunal for the Law of the Sea. Hague: Martinus Nijhoff.

Oral N. and J. Mitchell. Recent accidents at the Black Sea raise port state control concerns. www.turkishpilots.org/DOCUMENTS/N_Oral_Recent_Accidents.html

Ǿstergaard, John. 2004. International Energy Policy, the Arctic and the Law of the Sea: Oil Spill Contingency Planning and Technical Cooperation of the Black Sea Region. Leiden: Martinus Nijhoff: 189.

Plant, G. 2000. The Turkish Straits and Tanker traffic: An update. Marine Policy 24, no. 3 (May): 193-214.

Plant, G. 1996. Navigation regime in the Turkish Straits for merchant ships in peacetime. Marine Policy 20, no. 1: 15-27.

Scharfenberg, A. 1996. Regulating traffic flow in the Turkish Straits: A test for modern 
international law. Emory International Law Review 10, no. 1 (Spring ): 333-395.

Soligo, R. and A. Jaffe. 1999. The Economics of pipeline routes: The conundrum of oil exports from the Caspian Basin. http://riceinfo.rice.edu.projects/ baker/Pubs/Baker Pub/ publications/studi.../pipelines.htm.

Zhannikov, Dmitry. 2002. Novorossiisk sees growth despite Russian oil cut: 31 January 2002: Reuters.

BBC News World Edition, Giant Caspian oil pipeline opens, 25 May 2005 http://news.bbc.co.uk/ 2/hi/business/4577497.stm.

Development of Energy Policy for the Enlarged European Union, Its neighbours and partner countries COM (2003) final. http://ec.europa.eu/dgs/energy_transport/ international/ doc/2003_communication_en.pdf.

Directive 2002/59/EC of the European Parliament and of the Council of 27 June 2002 establishing a community vessel traffic monitoring and information system and repealing Council Directive 93/75: http://www.emsa.eu.int/Docs/ssn/dir\%202002\%2059\%20ec.pdf.

EU-Russia Energy Dialogue. 2003. Fourth progress report. http://ec.europa.eu/energy/russia/ joint progress/doc/progress4_en.pdf

COM. 2006. Green paper: A European strategy for sustainable, competitive and secure energy, 105. Final. http://ec.europa.eu/energy/green-paper-energy/doc/2006_03_08_gp_ document_en.pdf.

North Atlantic Treaty Organization (NATO) Report 252, Executive Summary. 2001. Environmental security of hazardous substances involved in oil and gas transportation in the Black sea and Caspian regions. http://www.pal.metu.edu.tr/Projeler/nato_ ccms.asp

Port State Control for the Black Sea Region. 2005. Annual Report. http://www.bsmou.org/ default2.htm

United Nations Conference on Trade and Development (UNCTAD). 2003. Review of Maritime Transport.

Turkish Republic Official Gazette

http://www.bsmou.org

http://www.chevrontexaco.com.

http://www.coastalsafety.gov.tr/

http://www.cpc.ru

http://www.eia.doe.gov/emeu/cabs/Russia/Oil_exports.html

http://www.eia.doe.gov/emeu/cabs/Caspian/Oil.html

http://www.eia.doe.gov/emeu/cabs/Azerbaijan/Oil.html

http:/www.euractiv.com/en/energy/eu-russia-energy-dialogue/article-150061

$\mathrm{http}: / /$ www.itopf.com/country_profiles/index.html.

http://www.turkishpilots.org 